\title{
MODAL KANDIDAT PEREMPUAN DALAM PILKADA TAHUN 2017 (STUDI KASUS: TJHAI CHUI MIE SEBAGAI WALIKOTA TERPILIH DI KOTA SINGKAWANG)
}

\author{
Ika Kartika \\ Program Pascasarjana Ilmu Politik Universitas Padjajaran Bandung \\ ika.fachrurrazi@gmail.com \\ Diterima: 5032019 Disetujui: 5062019 Dipublikasikan: 23062019
}

\begin{abstract}
This study is only trying to see the use of capital in relation to the victory of Tjhai Chui Mie in 2017 in Pilwako Singkawang. Tjhai Chui Mie managed to become the first mayor of ethnic Chinese women in Singkawang even in Indonesia. This study uses qualitative methods using data collection through in-depth interviews and document studies during the period April-June 2018. The results of this study Tjhai Chui Mie have social capital, economic capital, cultural capital and symbolic capital which can then be at stake to dominate by means of preserve or maintain its capital. Having a dominating position from the party and community organizations, the political experience he has built from being a member of the Singkawang City DPRD for 3 periods, and the full support of the ethnic Chinese to him from the Hakka tribe in Singkawang and ethnic Chinese businessmen in Jakarta and other cities makes Tjhai Chui Noodle is easy to build relationships and trust with the people who choose it.
\end{abstract}

\begin{abstract}
Abstrak: Penelitian ini hanya mencoba melihat pemanfaatan modal dalam kaitannya dengan kemenangan Tjhai Chui Mie pada Pilwako Singkawang Tahun 2017. Tjhai Chui Mie berhasil menjadi walikota perempuan etnis Tionghoa pertama di Singkawang bahkan di Indonesia. Penelitian ini menggunakan metode kualitatif dengan menggunakan pengumpulan data melalui wawancara mendalam dan studi dokumen dalam kurun waktu April-Juni 2018. Hasil penelitian ini Tjhai Chui Mie memiliki modal sosial, modal ekonomi, modal budaya dan modal simbolik yang kemudian dapat saling dipertaruhkan untuk mendominasi dengan cara melestarikan atau mempertahankan modal yang dimilikinya. Memiliki kedudukan yang mendominasi dari partai maupun organisasi masyarakat, pengalaman politik yang sudah dibangunnya dari menjadi anggota DPRD Kota Singkawang selama 3 periode, dan dukungan penuh dari etnis Tionghoa kepadanya baik dari suku Hakka di Singkawang maupun pengusaha etnis Tionghoa di Jakarta maupun kota lainnya membuat Tjhai Chui Mie mudah membangun relasi dan kepercayaan dengan masyarakat yang memilihnya.
\end{abstract}

Kata Kunci: Kandidat Perempuan, Kemenangan, Modal, Pilwako Singkawang.

\section{PENDAHULUAN}

Jumlah partisipasi politik perempuan masih rendah untuk menjadi calon kepala daerah. Tradisi masyarakat Indonesia yang cenderung patriarkis atau mengedepankan laki-laki dan ditambah anggapan bahwa politik bukan untuk perempuan merupakan salah satu faktor penyebab rendahnya partisipasi politik perempuan. Pandangan budaya di Indonesia melihat seorang perempuan adalah 
P-ISSN: 0216-4396

e-ISSN: 2655-6057
Jurnal Tapis: Jurnal Teropong Aspirasi Politik Islam 15 (5) (2019) 91-114

https:// http://ejournal.radenintan.ac.id/index.php/TAPIs/index

sukses apabila keluarganya juga terurus dan berhasil. Disisi lain, politisi perempuan dinilai terlibat dalam politik sebagai aktivitas sampingan karena keluarganya sudah terpenuhi kebutuhannya. Faktor lain yang membuat perempuan Indonesia kurang meminati dunia politik adalah anggapan tentang politik yang dikaitkan negatif seperti kotor, korup dan licik. ${ }^{1}$

Ini dapat dilihat pada penyelenggaraan Pilkada 2015, sebanyak 122 calon perempuan yang mencalonkan diri sebagai kandidat dari total 1.654 kandidat yang ditetapkan oleh Komisi Pemilihan Umum (KPU) atau hanya sebanyak 7,37\% calon perempuan yang maju menjadi kepala daerah. Sedangkan Pilkada 2017 diikuti oleh 45 calon perempuan yang mencalonkan diri sebagai kandidat dari total 620 kandidat yang ditetapkan oleh KPU atau hanya sebanyak 7,25\% calon perempuan yang maju dalam Pilkada ini. ${ }^{2}$

Hasil Pilkada tahun 2017 menunjukkan hanya 15 calon perempuan yang berhasil memenangkan kontestasi politik tersebut yaitu 8 orang menjadi Bupati, 3 orang sebagai Wakil Bupati, 2 orang menjadi Walikota, 1 orang sebagai Wakil Bupati, dan 1 orang menjadi Wakil Gubernur.Kota Singkawang merupakan salah satu daerah yang dipimpin oleh perempuan setelah Tjhai Chui Mie berhasil memenangkan Pilwako Singkawang Tahun 2017 yang diikuti oleh empat pasangan calon yang ditetap oleh KPU Kota Singkawang.

Tabel 1

Hasil perolehan suara Pilwako Singkawang tahun 2017

\begin{tabular}{|c|c|c|c|c|c|c|c|}
\hline \multirow{2}{*}{ No } & \multirow{2}{*}{$\begin{array}{c}\text { Nama } \\
\text { Pasangan Calon }\end{array}$} & \multicolumn{5}{|c|}{ Perolehan Suara Sah Setiap Kecamatan } & \multirow{2}{*}{$\begin{array}{l}\text { Jumlah } \\
\text { Akhir }\end{array}$} \\
\hline & & Tengah & Barat & Timur & Utara & Selatan & \\
\hline 1 & $\begin{array}{l}\text { Tjhai Nyit Kim, SH } \\
\text { dan } \\
\text { H. Suriyadi. MS, S.Sos, M.Si } \\
\text { (Golkar, PPP, PKPI ) }\end{array}$ & 2.928 & 3.000 & 1.777 & 1.234 & 3.300 & $\begin{array}{c}12.239 \\
(13,55 \%)\end{array}$ \\
\hline 2 & $\begin{array}{c}\text { Tjhai Chui Mie, SE } \\
\text { dan } \\
\text { Drs. H. Irwan, M.Si } \\
\text { (PDIP, Nasdem, Hanura, Demokrat) }\end{array}$ & 9.029 & 11.405 & 4.683 & 3.232 & 10.137 & $\begin{array}{c}38.486 \\
(42,63 \%)\end{array}$ \\
\hline 3 & $\begin{array}{l}\text { H. Abdul Mutalib, SE, ME } \\
\text { dan } \\
\text { Muhammadin, SE } \\
\text { (Gerindra, PKB, PAN, PKS) }\end{array}$ & 9.584 & 3.327 & 1.115 & 6.393 & 3.822 & $\begin{array}{c}24.241 \\
(26,85 \%\end{array}$ \\
\hline 4 & $\begin{array}{c}\text { Andi Syarif T.U.W, ST, MT, M.Si } \\
\text { dan } \\
\text { dr. H. Nurmansyah, M.Kes } \\
\text { (Perseorangan) }\end{array}$ & 6.763 & 2.022 & 1.496 & 2.463 & 2.577 & $\begin{array}{c}15.321 \\
(16,97 \%)\end{array}$ \\
\hline
\end{tabular}

Sumber: KPU Kota Singkawang

${ }^{1}$ Sharyn Graham Davies Nurul Ilmi Idrus, "Participating in Parliamentary Politics," Participating in Parliamentary Politics: Experiences of Indonesia Women 1995-2010”. Journal of Indonesia Social Sciences and Humanities, Vol. 3, 2010, 2010, hal. 92-94.

${ }^{2}$ KPU,Penyelenggaraan Pilkada Serentak 2015 dan 2017 (Jakarta: Komisi Pemilihan Umum, 2017, 2017), h. 211. 
P-ISSN: 0216-4396

e-ISSN: 2655-6057
Jurnal Tapis: Jurnal Teropong Aspirasi Politik Islam 15 (5) (2019) 91-114

https:// http://ejournal.radenintan.ac.id/index.php/TAPIs/index 
Kemenangan Tjhai Chui Mie cukup menarik karena menjadi walikota perempuan etnis Tionghoa pertama di Singkawang bahkan di Indonesia. Tjhai Chui Mie juga mengulangi keberhasilan politik etnik Cina di Singkawang setelah Bong Sau Fan alias Hasan Karman yang pernah menjadi Walikota Singkawang 2007 - 2012. Sebagai perempuan etnis Tionghoa dengan struktur budaya patriarkis, pada masa orde baru mereka mengalami diskriminasi ganda. Maksud dari diskriminasi ganda adalah mereka kaum perempuan yang merupakan etnis Tionghoa yang termasuk etnis minoritas dimana perempuan yang dianggap hanya untuk mengurus keluarga dan tingonghoa merupakan etnis yang minoritas di Indonesia. Mereka termarjinalisasi dalam kehidupan politik dikarenakan mereka perempuan dan mereka termarjinalisasi di kehidupan politik karena mereka berasal dari etnis minoritas yang seringkali menjadi "sasaran" bagi penguasa dalam mengatasi masalah-masalah sosial ekonomi yang akut. ${ }^{3}$ Sehingga adanya reformasi politik diharapkan marjinalisasi politik perempuan etnis Tionghoa bergerak ke arah pencerahan kehidupan politik termasuk kiprahnya dalam Pilkada seperti yang telah dilakukan oleh Tjhai Chui Mie.

Dalam konteks Pilkada, tentunya para kandidat mempunyai modal yang beragam untuk meraih kemenangan. Modal merupakan sumber daya politik yang dapat digunakan untuk memenangkan Pilkada. Pilkada merupakan arena kontestasi politik antara pihak-pihak yang memperebutkan kekuasaan untuk menjadi kepala daerah Pilkada selain untuk kontes politik antara pihak-pihak yang memperebutkan kekuasaan adapun untuk mempertahankan sebuah kekuasaan untuk menjadi kepala daerah. Kompetisi yang terjadi dalam Pilkada bukan hanya persaingan antar partai, tetapi lebih menonjolkan figur dari kandidat seperti ketokohan, popularitas, latar belakang pendidikan dan pekerjaan dan lain-lain. Modal ini yang dapat menjadi bangunan relasi dan kepercayaan (trust) yang dimiliki kandidat dengan masyarakat yang memilihnya.

Kemenangan calon perempuan dalam Pilkada tentunya tidak lepas dari faktor modal. Dalam pencalonan kandidat yang berkontestasi menjadi kepala daerah, salah satu dasar pertimbangan partai politik adalah melihat latar belakang kandidat, termasuk perempuan. Biaya politik yang mahal

${ }^{3}$ Al Rafni, “Akses dan Kontrol Politik Perempuan Etnis Cina dalam Pemilu Legislatif 2004 di Kota Padang," Al Rafni, "Akses dan Kontrol Politik Perempuan Etnis Cina dalam Pemilu Legislatif 2004 di Kota Padang”, Demokrasi Vol. VI No. 2, 2007, h. 2. 


\section{Mirnawati: CAPACITY BUILDING ORGANISASI; .....}

membuat partai politik seringkali berpikir pragmatis. Kandidat dengan modal finansial ataupun modal sosial yang besar menjadi pilihan utama partai politik. Sehingga tidak mengherankan banyak dari kandidat kepala daerah berlatar belakang pengusaha, pertahana ataupun birokrat. Pengusaha dianggap memiliki modal finansial yang kuat, sehingga dianggap mampu menanggung biaya kampanye yang mahal. Sementara petahana dan birokrat bisa memaksimalkan potensi struktur sosial dan politik dibawahnya untuk mobilisasi massa. ${ }^{4}$

Teori Modal tidak dapat dilepaskan dari sosiolog Pierre Bourdieu. Bourdieu menggolongkan modal ke dalam empat jenis yaitu: Pertama, modal ekonomi mencakup alat-alat produksi (mesin, tanah, buruh), materi (pendapatan dan benda-benda) dan uang yang dengan mudah digunakan untuk segala tujuan serta diwariskan dari satu generasi ke generasi berikutnya. Kedua, modal budaya adalah keseluruhan kualifikasi intelektual yang bisa diproduksi melalui pendidikan formal maupun warisan keluarga. Termasuk modal budaya antara lain kemampuan menampilkan diri di depan publik, pemilikan benda-benda budaya bernilai tinggi, pengetahuan dan keahlian tertentu dari hasil pendidikan, serta sertifikat (gelar kesarjanaan). Ketiga, modal sosial menunjuk pada jaringan sosial yang dimiliki pelaku (individu atau kelompok) dalam hubungannya dengan pihak lain yang memiliki kuasa. Keempat, segala bentuk prestise, status, otoritas dan legitimasi yang terakumulasi sebagai bentuk modal simbolik. Modal simbolik dapat diperoleh melalui posisi kedudukannya di tengah-tengah masyarakat atau kepemilikan modal yang dikonversi menjadi modal simbolik (sebagai orang terkaya, disegani atau dihormati), modal simbolik juga dapat diperoleh dari jabatan pada insitusi politik seperi pemerintahan eksekutif, legislatif dan partai politik. ${ }^{5}$

${ }^{4}$ Makrus Ali, “Pilkada Serentak 2017 : Menyambut Perempuan Kepala Daerah", diakses dari http://satunama.org/3703/pilkada-serentak-2017menyambut-perempuan-kepala-daerah/pada tanggal 30 Agustus 2018.,

${ }^{5}$ Fauzi Fashri, Pierre Bourdie, Menyingkap Kuasa Simbol, (Yogyakarta: Jalasutra, 2014), h. 109. 


\section{Mirnawati: CAPACITY BUILDING ORGANISASI; .....}

Modal bagi Bourdieu yaitu berperan sebagai sebuah relasi sosial yang terdapat didalam suatu sistem pertukaran, dan istilah ini diperluas pada segala bentuk barang baik material maupun simbol, tanpa perbedaan- yang mempresentasikan dirinya sebagai sesuatu yang jarang dan layak untuk dicari dalam sebuah formasi sosial tertentu. Beragam jenis modal dapat dipertukarkan dengan jenis-jenis modal lainnya, yang artinya modal bersifat"dapat ditukar". ${ }^{6}$ Contoh dari modal yang bersifat dapat ditukar misalkan seseorang yang memiliki modal ekonomi berupa orang yang memiliki uang untuk mendapatkan tujuan dapatditukar dengan modal simbolik . Bourdieu juga menjelaskan modal akan eksis dan berfungsi dalam arena serta memiliki kekuatan terhadap arena sehingga ia menentukan keuntungan-keuntungan yang diperoleh para aktor di dalam arena. Kemudian modal tersebut dimanfaatkan aktor untuk memperkuat (mempertahankan atau merebut) kedudukan aktor di arena. Oleh karena itu pertarungan dalam arena harus memiliki modal dan kemampuan strategi dalam menggunakan modal tersebut sehingga aktor memperoleh dan dapat mempertahankan posisi yang diinginkan dalam arena itu.

Beberapa peneliti telah mendiskusikan tentang kemenangan calon perempuan yang kemudian menjadi kepala daerah.Baharuddin \& Purwaningsih (2017) menganalisis modalitas calon bupati dalam tahun 2015 dengan studi kasus kemenangan Indah Putri Indriani sebagai Bupati di Kabupaten Luwu Utara Provinsi Sulawesi Selatan. Hasil penelitiannya mengungkapkan Indah Putri Indriani memiliki modal sosial, politik, budaya dan ekonomi sehingga berhasil terpilih menjadi Bupati Luwu Utara Periode 2015-2020 sekaligus menjadi bupati perempuan pertama di Sulawesi Selatan. Diantara keempat modal tersebut, modalitas dominannya adalah modal politik.

Yayasan Satu Nama (2016) mengkaji perspektif perempuan dan

${ }^{6}$ Richard Harker, (Habitus $x$ Modal) + Ranah = Praktik (Pengantar Paling Komprehensif kepada Pemikiran Pierre Bourdieu) (Yogyakarta: Jalasutra, 2009), h. 16.

7 "Ruang Pertarungan dan Strategi Aktor di Arena Ekonomi Politik Lokal", Jurnal Sosial Humaniora, Vol.02, 2011," Ruang Pertarungan dan Strategi Aktor di Arena Ekonomi Politik Lokal", Jurnal Sosial Humaniora, Vol.02, 2011, h. 64. 


\section{Mirnawati: CAPACITY BUILDING ORGANISASI; .....}

lingkar kekuasan di sekitaran calon perempuan peserta pilkada serentak 2015. Hasil kajiannya adalah jumlah perempuan yang menjadi kandidat pada pilkada serentak 2015 masih sangat kecil yaitu sekitar 7,3\% dan hanya sebanyak 47 perempuan yang terpilih sebagai kepala daerah. Sebanyak 39 perempuan dari 47 perempuan yang terpilih berasal dari latar belakang yang secara finansial dan modal sosial memungkinkan atau memudahkan mereka terpilih, yaitu 13 perempuan adalah petahana, 12 perempuan dari kalangan legislatif serta 7 perempuan dari birokrat dan 7 perempuan pengusaha. Dan lebih dari separuh atau 33 perempuan yang terpilih memiliki perspektif perempuan dengan beragam isu yaitu, politik, kesehatan, sosial, ekonomi, dan pendidikan.

Penelitian ini mencoba mengkaji secara komprehensif tentang bagaimana Tjhai Chui Mie memanfaatkan modal sosial, modal ekonomi, modal budaya dan modal simbolik yang dimilikinya sehingga memenangkan Pemilihan Walikota Singkawang Tahun 2017.Karena dalam menentukan strategi pemenangan tidak hanya menyesuaikan kondisi dan arena kompetisi tetapi juga termasuk modal yang dimiliki kandidat. Apalagi kepemilikan modal ini merupakan salah satu permasalahan yang sering dihadapi oleh perempuan untuk terlibat dalam politik.

\section{METODE}

Pendekatan penelitian yang digunakan adalah penelitian kualitatif dekriptif dengan model studi kasus. Penelitian kualitatif merupakan penelitian yang bermaksud untuk memahami fenomena tentang apa yang dialami oleh subjek penelitian misalnya perilaku, persepsi, motivasi, tindakan, secara holistik, dan dengan cara deskripsi dalam bentuk kata-kata dan bahasa, pada suatu konteks khusus yang alamiah dan dengan memanfaatkan berbagai metode alamiah. ${ }^{8}$ Penelitian ini dilakukan dengan menggunakan metode pengumpulan data berupa studi dokumentasi dan wawancara mendalam yang melibatkan informan dari berbagai latar belakang seperti Walikota Singkawang Terpilih, Wakil Ketua DPRD

${ }^{8}$ Lexy J. Moleong, "Metodologi Penelitian Kualitatif, (Bandung: PT. Remaja Rosdakarya, 2005), h. 6. 


\section{Mirnawati: CAPACITY BUILDING ORGANISASI; .....}

Singkawang, Pengurus Partai Politik, Sekretaris dan Tim Kreatif Pemenangan, Pengurus Komunitas Perempuan Hebat Singkawang, Akademisi, dan masyarakat.

Penelitian dilakukan selama kurang lebih tiga bulan pada tahun 2018 di Kota Singkawang. Informan ditentukan dengan cara mendasarkan pada relevansi informan dengandata yang dibutuhkan. Analisis data mengikuti tahapan analisis yang digagas Miles \& Huberman yaitu yaitu pengumpulan data (data collection), reduksi data (data reduction), penyajian data (data display), dan penarikan kesimpulan atau verifikasi (conclutions). ${ }^{9}$

\section{HASIL DAN PEMBAHASAN}

\section{Modal Sosial}

Bourdieu mendefinisikan modal sosial dapat berasal dari jaringan sosial yang terlembagakan serta berlangsung terus menerus dalam bentuk pengakuan dan perkenalan timbal balik (atau dengan kata lain: keanggotaan dalam kelompok sosial) yang memberikan kepada anggotanya berbagai bentuk dukungan kolektif. Modal sosial yang dimiliki seseorang tergantung pada jaringan hubungan yang dapat dimobilisasikannya secara efektif. ${ }^{10}$

Modal sosial yang dimiliki Tjhai Chui Mie adalah pertama, interaksi sosial yang dilakukannya dengan masyarakat yang sudah terbangun sejak lama berupa rajin melakukan kegiatan sosial sehingga sosoknya dikenal oleh masyarakat. Tjhai Chui Mie rajin melakukan kegiatan sosial dari 20 (dua puluh tahun ) yang lalu. Setiap ada bencana alam atau terdapat musibah,

\footnotetext{
${ }^{9}$ Mathew B. Miles A. Michael Huberman, Analisis Data Kualitatif,
} (Jakarta: Universitas Indonesia, 1992) (Jakarta: Universitas Indonesia, 1992), h. 1620.

${ }^{10}$ Pierre Bourdieu, Handbook and Theory of Research for the Sociology of Education, (New York: Greenwood, 1986), (New York: Greenwood, 1986), h. 251. 


\section{Mirnawati: CAPACITY BUILDING ORGANISASI; .....}

Tjhai Chui Mie merupakan sosok yang selalu turun ke lapangan untuk membantu masyarakat tanpa membeda-bedakan etnisitas. ${ }^{11}$

Kedua, jaringan relasi Tjhai Chui Mie sebagai Ketua Perkumpulan Hakka Indonesia Kota Singkawang, Ketua Majelis Tao Indonesia (MTI) Kota Singkawang dan Dewan Kehormatan Yayasan Setia Negara, Serpong. Dengan pengalaman organisasi yang ada, kemenangan Tjhai Chui Mie tidak dapat dilepaskan dari jaringan relasi yang dibuatnya dengan masyarakat atau pengusaha-pengusaha Singkawang yang berada di Jakarta. Mereka ini yang bergabung di Permasis (Perkumpulan Masyarakat Singkawang dan Sekitarnya). Dukungannya bukan hanya sumber pendanaan kampanye, lebih penting lagi mereka berpengaruh diantara kerabat di Singkawang dan dukungan mereka dapat membantu para kandidat untuk mendapatkan suara etnis Tionghoa.

Tjhai Nyit Kim dan Tjhai Chui Mie yang merupakan kandidat yang berasal dari etnis Tionghoa mengakui pengaruh elit Tionghoa Singkawang di Jakarta dan mereka juga "berkampanye" di Jakarta untuk mencari dukungan elit ini. Elit ini bukan hanya sumber pendanaan kampanye, lebih penting lagi mereka berpengaruh diantara kerabat di Singkawang dan dukungan mereka dapat membantu para kandidat untuk mendapatkan suara etnis Tionghoa. Dilihat dari laporan sumbangan kampanye dari kedua kandidat ini, Tjhai Chui Mie tampak lebih berhasil dalam mendapatkan dukungan dari elit Tionghoa Singkawang di Jakarta. ${ }^{12}$

Ketiga, kepercayaan masyarakat yang tinggi kepada Tjhai Chui Mie. Fukuyama mengungkapkan bahwa terdapat hubungan antara modal sosial dan trust (kepercayaan). Trust adalah sikap saling mempercayai di

${ }^{11}$ Tjit Min, "pemilih di Kecamatan Singkawang Timur, wawancara tanggal 30 April 2018,"

${ }^{12}$ Hui-Yew Foong, Hui-Yew-Foong, "Decentralization and Chinese Indonesian Politics: The Case of Singkawang, West Kalimantan,"ISEAS Perspective No. 19 (Kalimantan: ISEAS Perspective No. 19, 2017, 2017), h. 7. 


\section{Mirnawati: CAPACITY BUILDING ORGANISASI; .....}

masyarakat yang memungkinkan masyarakat tersebut saling bersatu dengan yang lain dan memberikan kontribusi pada peningkatan modal sosial. ${ }^{13}$

Tjhai Chui Mie berhasil memenangkan Pilwako Singkawang karena faktor track record beliau sebagai Anggota DPRD Kota Singkawang dan sosok yang dekat dengan masyarakat dengan kegiatan sosialnya. Latar belakang beliau yang berasal dari etnis Tionghoa sehingga memiliki hubungan kekeluargaan secara emosional dengan etnis Tionghoa di Singkawang juga tidak dapat dilepaskan karena dukungan penuh etnis Tionghoa kepada beliau. ${ }^{14}$

Bahkan kepercayaan masyarakat Kota Singkawang tidak luntur kepada Tjhai Chui Mie meskipun ia diterpa masalah tersebarnya kalender palu arit. Sekitar 1000 (seribu) kalender impor yang berisikan penanggalan hari baik maupun hari buruk berdasarkan fengshui yang diyakini dan pada bagian tanggal 1 juli dari kalender tersebut terdapat lambang palu arit. Keberadaan gambar palu arit pada tanggal 1 juli merupakan hari besar bagi Republik Rakyat Tiongkok (kembalinya Hongkong kepada Republik Rakyat Tiongkok). ${ }^{15}$

Karena masalah kalender ini, Tjhai Chui Mie selalu dikaitkan dengan PKI. Tetapi Tjhai Chui Mie dan tim kampanye berhasil mematahkan isu tersebut dengan strategi kampanye yang tepat. Ketika isu PKI beredar, Tjhai Chui Mie dalam kampanyenya selalu mengungkapkan NKRI harga mati. Selain isu PKI, Tjhai Chui Mie juga dikaitkan dengan sentimen agama dan etnis. Dalam hal ini sosok Irwan sebagai calon Wakil Walikota lah yang

${ }^{13}$ Francis Fukuyama, "Trust Kebijakan Sosial dan Penciptaan Kemakmuran, (Yogyakarta: Qalam, 2002)," Francis Fukuyama, Trust Kebijakan Sosial dan Penciptaan Kemakmuran, (Yogyakarta: Qalam, 2002), 2002, h. xii.

${ }^{14}$ Rahmaniah, "Syarifah Ema Rahmaniah, Akademisi, wawancara tanggal 28 Juni 2018.," Akademisi, wawancara tanggal 28 Juni 2018, 2018.

${ }^{15}$ Novie Saputra, “Bagikan Seribu Kalender Berlambang Palu Arit, Ini Tanggapan Dewan Singkawang", Diakses dari http://pontianak.tribunnews.com/2016/06/30/bagikan-15-ribu-kalender-yangberlambang-palu-arit-ini-tanggapan-dewan-singkawang pada tanggal 10 Agustus 2018," 2018. 


\section{Mirnawati: CAPACITY BUILDING ORGANISASI; .....}

berperan karena ia berasal dari etnis Melayu sehingga bisa merangkul suara Melayu dan Islam. Untuk mematahkan sentimen agama dan etnis tersebut, Tjhai Chui Mie merangkul tokoh agama, tokoh masyararakat semua etnis dan berkampanye dengan memakai pakaian adat semua etnis di Singkawang.

Kampanye dengan menggunakan tema nasionalisme, seperti Pancasila, Bhinneka Tunggal Ika, NKRI, memang menjadi salah satu tema yang digunakan oleh Etnis Tionghoa ketika turun berpolitik. Karena ketika etnis Tionghoa terlibat dalam politik selalu dikaitkan dengan ideologi komunis atau ideologi yang mempunyai manifestasi dengan ideologi negara cina sebagai ideologi negara leluhurnya. Karena itulah ketika Tjhai Chui Mie diserang oleh isu PKI karena penyebaran kalender palu arit, tema nasionalisme memang selalu diangkat ketika kampanye.

Menjadi Calon Walikota Perempuan merupakan tantangan tersendiri bagi Tjhai Chui Mie. Ia bersama timnya berusaha ketika kampanye selalu berusaha menjadikan sosoknya sebagai perempuan menjadi kelebihan bukan sebagai kekurangan. Dalam memilih isu kampanye, Petrocik menjelaskan "issue ownership" yang mengungkapkan bahwa kandidat harus menekankan isu-isu yang mereka kuasai dan menghindari isu-isu yang dikuasai oleh lawan mereka. Seperti halnya kandidat perempuan dianggap lebih mahir dalam menangani isu-isu seperti pendidikan dan kesejahteraan sosial. ${ }^{16}$

Tjhai Chui Mie selalu menekankan perempuan bisa menjadi pemimpin dalam kampanyenya. Salah satu yang dijual ketika kampanye adalah program untuk perempuan khususnya pendidikan dan kesehatan bagi ibu dan anak. Komitmennya untuk memajukan perempuan Singkawang dibuktikan dengan lahirnya Komunitas Perempuan Hebat seperti janji

${ }^{16}$ Jason Windett, Understanding Female Candidates and Campaign,. (Chapel Hill: University of North Carolina, 2011) (Chapel Hill, Carolina: University of North Carolina, 2011), h. 65. 


\section{Mirnawati: CAPACITY BUILDING ORGANISASI; .....}

kampanyenya. Komunitas Perempuan Hebat bergerak di bidang sosial termasuk di dalamnya pendidikan politik bagi perempuan. ${ }^{17}$

Memiliki modal sosial yang dominan berupa selalu memiliki interaksi dengan masyarakat Singkawang melalui kegiatan sosialnya, jaringan relasi yang luas dan memiliki kepercayaan dari masyarakat Singkawang maka Tjhai Chui Mie berusaha mempertahankan kepemilikan modal sosialnya sebagai strateginya. Dengan segala track recordnya, Tjhai Chui Mie berhasil mendapatkan dukungan dari elit politik, tokoh agama maupun tokoh masyarakat lintas etnis yang membantunya sehingga bisa memperoleh kemenangan dalam Pilwako Singkawang Tahun 2017.

Dalam konteks lokal (daerah) banyak terdapat elit-elit yang menduduki jabatan politik dan jabatan-jabatan strategis yang mempunyai peran penting dan pengaruh terhadap kelompok dan masyarakat di daerah tersebut. Hal itu membuat dukungan mereka memang dapat membantu kandidat dalam memperoleh dukungan suara dari masyarakat. Elit Politik Lokal adalah mereka yang memiliki jabatan politik tinggi di tingkat lokal yang membuat dan menjalankan kebijakan politik. Elit politiknya seperti Gubernur, Bupati, Walikota, Ketua DPRD, Anggota DPRD, maupun pemimpin-pemimpin partai yang ada di tingkat daerah. Elit Non-Politik Lokal adalah seseorang yang menduduki jabatan-jabatan strategis dan mempunyai pengaruh untuk memerintah orang lain dalam lingkup masyarakat. Elit non politik ini seperti elit keagamaan, elit organisasi masyarakat, kepemudaan, profesi dan lain sebagainya. ${ }^{18}$

Hal ini terbukti ketika kampanye, elit politik, tokoh masyarakat maupun pengusaha etnis Tionghoa hadir mendukung. Mereka bersedia meluangkan waktu dan tenaga bahkan datang dari luar Kota Singkawang. Beberapa tokoh yang mendukung Tjhai Chui Mie hadir ketika kampanye

${ }^{17}$ Fitri Agus Lestari, Pengurus Perempuan Hebat Singkawang, wawancara tanggal 3 Mei 2018. (Singkawang, 2018).

${ }^{18}$ Moch Nurhasim, "Konflik antar Elit Politik Lokal dalam Pemilihan Kepala Daerah," Konflik antar Elit Politik Lokal dalam Pemilihan Kepala Daerah, (Jakarta: Pusat Penelitian Politik (P2P) LIPI, 2003), 2003, h. 8. 


\section{Mirnawati: CAPACITY BUILDING ORGANISASI; .....}

antara lain Cornelis dan Cristiandy Sanjaya (Gubernur dan Wakil Gubernur Kalimantan Barat), Hasan Karman (Mantan Walikota Singkawang Tahun 2007-2012), Lazarus dan Michael Jenno (Anggota DPR RI), Aloysius Kilim (Ketua Adat Dayak Kota Singkawang), Uray Rukiyat (Walikota Administratif Singkawang 1984-1988). Dengan jaringan relasi yang dimilikinya, Tjhai Chui Mie juga berhasil menarik dukungan dari pengusaha-pengusaha Etnis Tionghoa Jakarta yang turut hadir ketika kampanye seperti Rudi Halim dan Tenggono Chuandra.

\section{Modal Ekonomi}

Bourdieu mengungkapkan modal ekonomi merupakan jenis modal yang mudah dikonversikan ke dalam bentuk-bentuk modal lainnya. Modal ekonomi mencakup alat-alat produksi (mesin, tanah, buruh), materi (pendapatan dan benda-benda), dan uang. Semua jenis modal ini mudah digunakan untuk segala tujuan serta diwariskan dari generasi ke generasi. ${ }^{19}$

Modal ekonomi salah satu menjadi ukuran penting yang harus dimiliki oleh kandidat untuk memenangkan kompetisi di dalam Pilkada diantaranya jumlah harta kekayaan pribadi dan dana sumbangan kampanye. Modal ekonomi tersebut berfungsi sebagai penggerak mesin politik yang dipakai terutama pada saat kampanye. Kampanye adalah kegiatan menawarkan visi, misi, dan program pasangan calon dan/atau informasi lainnya, yang bertujuan mengenalkan atau meyakinkan pemilih.

Modal ekonomi yang dimiliki Tjhai Chui Mie berupa harta kekayaan dan dana kampanye. Modal ekonomi tersebut berfungsi sebagai penggerak mesin politik yang dipakai terutama pada saat kampanye.Harta kekayaan yang dimiliki oleh Tjhai Chui Mie jika dibandingkan dengan kandidat lainnya terdapat perbedaan yang siginifikan. Harta kekayaan Tjhai Chui Mie tergolong paling sedikit dibandingkan kandidat calon walikota lainnya.

${ }^{19}$ Fashri Fauzi, Penyingkapan Kuasa Simbol: Apropriasi Reflektif Pemikiran Pierre Bourdieu, (Yogyakarta: Juxtapose, 2007), h. 98-99. 


\section{Mirnawati: CAPACITY BUILDING ORGANISASI; .....}

Tabel 2

Harta kekayaan

Calon Walikota dan Wakil Walikota Singkawang Tahun 2017

\begin{tabular}{|c|l|l|}
\hline No & Nama Pasangan Calon & Harta Kekayaan \\
\hline 1 & $\begin{array}{l}\text { Tjhai Nyit Kim, SH } \\
\text { H. Suriyadi. MS, S.Sos, M.Si }\end{array}$ & $\begin{array}{l}\text { Rp.1.027.154.000 } \\
\text { Rp.1.614.145.865 }\end{array}$ \\
\hline 2 & $\begin{array}{l}\text { Tjhai Chui Mie, SE } \\
\text { Drs. H. Irwan, M.Si }\end{array}$ & $\begin{array}{l}\text { Rp.653.223.369 } \\
\text { Rp.295.145.865 }\end{array}$ \\
\hline 3 & $\begin{array}{l}\text { H. Abdul Muthalib, SE, ME } \\
\text { Muhammadin, SE }\end{array}$ & $\begin{array}{l}\text { Rp.15.083.177.004 } \\
\text { Rp.1.023.000.000 }\end{array}$ \\
\hline 4 & $\begin{array}{l}\text { Andi Syarif, T.U.W., ST, MT, M.Si } \\
\text { (Han) } \\
\text { dr. H. Nurmansyah, M.Kes }\end{array}$ & Rp.12.419.642.890 \\
\hline
\end{tabular}

Sumber: KPU Kota Singkawang

Walaupun harta kekayaan Tjhai Chui Mie lebih sedikit dibanding kandidat lain, tetapi tidak menjadikannya satu-satunya modal yang dipunya untuk memenangkan Pilwako Singkawang tahun 2017. Kepemilikan dana kampanye juga penting. Dana kampanye menjadi pokok pengaturan penting dalam UU No. 8 Tahun 2015 jo UU No. 10 Tahun 2016 tentang Pilkada. KPU juga telah mengeluarkan peraturan teknis mengenai dana kampanye dalam PKPU No. 8 tahun 2015 jo PKPU No. 13 Tahun 2016. Pengaturan dana kampanye ini bertujuan untuk menciptakan lapangan kontestasi yang setara antar kandidat, mencegah korupsi pilkada dan potensi korupsi akibat tingginya biaya pemenangan pilkada, mencegah 


\section{Mirnawati: CAPACITY BUILDING ORGANISASI; .....}

pilkada menjadi kesempatan melakukan tindak pidana pencucian uang dan instrumen kepentingan bisnis, dan menjaga integritas pilkada dari segi pendanaan.

Dalam pelaksaaan Pilkada serentak 2017 berdasarkan PKPU no 12 Tahun 2016, kampanye oleh kandidat dapat dilakukan dalam bentuk pertemuan terbatas, tatap muka atau dialog, pemasangan bahan kampanye, pemasangan alat peraga kampanye, dan kegiatan lain yang tak melanggar aturan. KPU setempat dapat memfasilitasi kampanye yaitu debat publik, penyebaran bahan kampanye, pemasangan alat peraga kampanye, dan iklan di media massa. Selain itu juga diatur pembatasan dana kampanye. Adapun dana kampanye setiap paslon pada Pilwako Singkawang Tahun 2017 dapat dilihat pada tabel dibawah ini:

Tabel 3

Laporan Penerimaan dan Pengeluaran Dana Kampanye

Pilwako Singkawang Tahun 2017

\begin{tabular}{c|c|c|c|c}
\hline $\begin{array}{c}\text { N } \\
\mathbf{0}\end{array}$ & $\begin{array}{c}\text { Nama } \\
\text { Pasangan Calon }\end{array}$ & $\begin{array}{c}\text { Pembatasan } \\
\text { Pengeluaran Dana } \\
\text { Kampanye }\end{array}$ & $\begin{array}{c}\text { Jumlah } \\
\text { Penerimaan }\end{array}$ & $\begin{array}{c}\text { Jumlah } \\
\text { Pengeluara }\end{array}$ \\
\hline 1 & $\begin{array}{c}\text { Tjhai Nyit Kim, SH } \\
\text { dan }\end{array}$ & Rp.2.900.157.650,- & Rp.1.2000.000.000,- & Rp.1.199.230.0 \\
& H. Suriyadi. MS, S.Sos, M.Si & & & \\
\hline
\end{tabular}

20 “'ICW, 'Dana Kampanye dan Masa Kritis Pilkada 2017', Diakses dari https://antikorupsi.org/sites/default/files/files/Siaran\%20Pers/Rilis\%20dana\%20kam panye $\% 20$ dan\%20masa\%20kritis\%20pilkada.pdf, pada tanggal 19 September 2018," 


\section{Mirnawati: CAPACITY BUILDING ORGANISASI; .....}

\begin{tabular}{c|c|c|c|c}
\hline 2 & $\begin{array}{c}\text { Tjhai Chui Mie, SE } \\
\text { dan } \\
\text { Drs. H. Irwan, M.Si }\end{array}$ & Rp.2.900.157.650,- & Rp.931.900.000,- & Rp.892.543.700 \\
\hline 3 & $\begin{array}{c}\text { H. Abdul Mutalib, SE, ME } \\
\text { dan } \\
\text { Muhammadin, SE }\end{array}$ & Rp.2.900.157.650,- & Rp.1.007.527.333,- & Rp.1.006.314.0 \\
\hline 4 & $\begin{array}{c}\text { Andi Syarif T.U.W, ST, MT, } \\
\text { M.Si (Han) } \\
\text { dan } \\
\text { dr. H. Nurmansyah, M.Kes }\end{array}$ & Rp.2.900.157.650,- & Rp.135.000.000,- & Rp.127.900.000 \\
\hline
\end{tabular}

Sumber: KPU Kota Singkawang

Jumlah penerimaan dan pengeluaran dana kampanye pasangan Tjhai Chui Mie dan Irwan memang lebih sedikit dibanding paslon lain yang diusung oleh partai. Tetapi dilihat dari hasil audit Laporan Penerimaan dan Pengeluaran Dana Kampanye (LPPPDK), Tjhai Chui Mie berhasil memanfaatkan dana kampanye yang ada dengan baik yaitu digunakan sebagian besar untuk pertemuan tatap muka atau blusukan langsung ke rumah-rumah masyarakat. Lain hal dengan kandidat yang lain seperti Tjhai Nyit Kim ataupun Abdul Mutalib yang kampanyenya sebagian besar untuk pertemuan terbatas yang hanya sebatas orasi program. Tjhai Chui Mie memanfaatkan pertemuan tatap muka supaya langsung mengetahui permasalahan yang ada di masyarakat.

Tjhai Chui Mie berhasil memanfaatkan modal sosialnya sehingga membantunya dalam dana kampanye yang ada berhasil dimanfaatkan secara efektif. Tjhai Chui Mie mendapat dukungan individu berupa sumbangan perseorangan dan sumbangan badan hukum swasta terhadap pendanaan kampanyenya. Partai pengusung juga berusaha membantu dalam hal dana kampanye. PDIP misalnya ada BKO dimana daerah yang tidak melaksanakan Pilkada tetapi kader PDIP di daerah tersebut turun membantu 


\section{Mirnawati: CAPACITY BUILDING ORGANISASI; .....}

ke Singkawang sehingga dari atas sampai bawah, semua kader gotong royong baik dari PAC, DPC, DPD bahkan DPP. ${ }^{21}$

Dengan dana kampanye yang ada dan memiliki jumlah yang lebih sedikit dibanding Paslon lain yang diusung oleh partai, Tjhai Chui Mie juga berhasil memanfaatkannya dengan baik dengan strategi kampanye melalui offline dan online. Ketika Paslon lain hanya berkutat dengan strategi kampanye offline yaitu dialogis dengan masyarakat, Tjhai Chui Mie berhasil melakukan kampanye secara offline dan online untuk masuk ke pasar pemilih muda. Dalam media sosial sebagai media kampanye terdapat pages Facebook "Tjhai Chui Mie", Instagram "Tjhai Chui Mie", dan You Tube "Tjhai Chui Mie", website http://tcm.ilmci.com bahkan Aplikasi Games "TCM4SKW" yang bisa didownload untuk android. Untuk kegiatan pemilih muda ada gerakan 10.000 selfie pendukung Tjhai Chui Mie untuk agen perubahan, membuat acara flashmob terbesar di Singkawang pada bulan Januari 2017, seminggu sekali mengadakan kegiatan "nogok plus plus" yang artinya nongkrong sambil diskusi positif misalnya bagaimana kedepannya Kota Singkawang. ${ }^{22}$

\section{Modal Budaya}

Bourdieu menyatakan modal budaya merupakan keseluruhan kualifikasi intelektual yang bisa diproduksi melalui pendidikan formal maupun warisan keluarga, seperti kemampuan menampilkan diri di depan publik, kepemilikan benda-benda budaya bernilai tinggi, pengetahuan atau keahlian tertentu hasil pendidikan formal, sertifikat (termasuk gelar kesarjanaan), bentuk-bentuk bahasa dan lain-lain. ${ }^{23}$ Individu memperoleh modal budaya ini sejak ia kecil dimana modal ini sudah terbentuk dan terinternalisasi secara sendiri, salah satunya melalui ajaran orang tuanya dan

\footnotetext{
${ }^{21}$ Ami, “ Bendahara DPC PDIP Singkawang, wawancara tanggal 3 Mei 2018," .

${ }^{22}$ Junaedi, "Trino Junaedi, Tim Kreatif Pemenangan Paslon CHAIR/ Barisan Biak CHAIR, wawancara tanggal 3 Mei 2018,”.

${ }^{23}$ Abd Halim, Politik Lokal; Pola, Aktor \& Alur Dramatikalnya, (Yogyakarta: LP2B, 2014), h. 110.
} 


\section{Mirnawati: CAPACITY BUILDING ORGANISASI; .....}

pengaruh lingkungan keluarganya. Dapat dikatakan bahwa modal budaya ini dibentuk sendiri oleh lingkungan sosial yang beranekaragam serta pendidikan yang diperoleh individu tersebut, pendidikan tersebut bisa berupa pendidikan formal maupun warisan budaya dari keluarga.

Modal budaya yang dimiliki Tjhai Chui Mie adalah pendidikan formal dan warisan budaya dari keluarga. Saat ini Tjhai Chui Mie sedang melanjutkan pendidikan pasca sarjananya di Universitas Tanjungpura Fakultas Hukum Jurusan Otonomi Daerah. Sebagai serorang perempuan dengan kesibukannya setelah menjabat menjadi Walikota Singkawang dan waktu untuk mengurus keluarga tidak membuat Tjhai Chui Mie lupa untuk melanjutkan pendidikannya ke jenjang yang lebih tinggi setelah lulus menjadi Sarjana Ekonomi pada tahun 2011 yang lalu di STIE Mulia Singkawang. Dalam hal pendidikan formal yang dimiliki Tjhai Chui Mie memang tidak secara langsung berpengaruh pada kemenangannya menjadi Walikota Singkawang. Status pendidikan yang diraih oleh para kandidat sejatinya merupakan nilai tambahan bagi masyarakat bahwa kandidat yang dipilih adalah orang yang tepat karena memiliki tingkat pengetahuan yang cukup dalam mengambil suatu kebijakan.

Tjhai Chui Mie berasal dari etnis Tionghoa suku Hakka yang beragama Budha. Warisan budaya dari keluarga inilah menjadi kekuatan Tjhai Chui Mie dalam meriah kemenangannya dikarenakan dukungan yang penuh dari etnis Tionghoa apalagi mayoritas etnis Tionghoa di Singkawang berasal dari Suku Hakka. Suku Hakka tersebar di seluruh kecamatan di Singkawang, tetapi terutama banyak di Singkawang Barat dan Singkawang Selatan di mana dua kecamatan inilah suara Tjhai Chui Mie menang telak. Sejak Pilwako 2007 yaitu ketika Hasan Karman terpilih, etnis Tionghoa tetap memilih sesama etnis Tionghoa. Walaupun ada Tjhai Nyit Kim yang sesama Tionghoa, hanya sedikit etnis Tionghoa memilihnya karena pengaruh agama. Menurut etnis Tionghoa, ketika ia keluar dari agamanya maka bukan lagi merupakan etnis Tionghoa. Tjhai Nyit Kim merupakan etnis Tionghoa beragama Islam, sehingga etnis Tionghoa yang bertarung hanya dianggap satu yaitu Tjhai Chui Mie.

Sebagai ketua Perhakin Kota Singkawang, juga secara tidak langsung membantu dalam kampanye. Hakka mempunyai media masa 


\section{Mirnawati: CAPACITY BUILDING ORGANISASI; .....}

sendiri seperti koran tetapi menggunakan bahasa mandarin. Cetak korannya itu tidak hanya di Singkawang, tetapi di Jakarta juga ada. Selain koran juga terdapat website Hakka Indonesia http://hakkaindonesia.or.id/ di mana di website tersebut juga terdapat berita terkini kegiatan yang dilakukan Tjhai Chui Mie. Sehingga Tjhai Chui Mie bukan hanya dikenal sebagai tokoh Hakka di Singkawang, akan tetapi juga sebagai penggerak dan pemelihara kegiatan-kegiatan Hakka di Singkawang selama ini.

Tjhai Chui Mie juga mempertahankan modal budaya yang dimilikinya. Bahkan status Tjhai Chui Mie sebagai etnis Tionghoa suku Hakka tentunya memberikan keuntungan tersendiri ketika kampanye. Tjhai Chui Mie menggunakan dua bahasa yaitu bahasa Indonesia dan bahasa Hakka/Khek untuk berdiskusi dengan masyarakat Singkawang ketika kampanye. Karena di kalangan Tionghoa banyak orang tua tidak begitu mengerti bahasa Indonesia, serta untuk kalangan Tionghoa sendiri kadang ada terkesan rasa takut, bahkan untuk maju ke depan pada saat kampanye dialogis saja mereka takut. Jadi menggunakan bahasa Hakka merupakan salah satu cara memudahkan untuk mereka mengerti. ${ }^{24}$

\section{Modal Simbolik}

Kekuasaan simbolik membutuhkan simbol-simbol kekuasaan seperti jabatan, mobil mewah, kantor, prestise, gelar, status tinggi dan keluarga ternama. Artinya modal simbolik adalah semua bentuk pengakuan oleh kelompok baik secara institusional atau non-institusional. Simbol ini memiliki kekuatan untuk mengkrontruksi realitas, yang mampu menggiring orang untuk mempercayai, mengakui dan mengubah pandangan mereka tentang realitas seseorang, sekelompok orang, sebuat partai politik atau sebuah bangsa. ${ }^{25}$

Modal simbolik yang dimiliki Tjhai Chui Mie adalah politikus perempuan sebagai anggota DPRD Kota Singkawang selama tiga periode dimana karirnya dimulai pada saat dilantik menjadi anggota DPRD Kota

${ }^{24}$ Yulius Yoris Anes, "Yulius Yoris Anes, Sekretaris Tim Pemenangan Paslon CHAIR, wawancara tanggal 4 Juni 2018," 2018.

${ }^{25}$ Op.cit, hal. 111, 


\section{Mirnawati: CAPACITY BUILDING ORGANISASI; .....}

Singkawang periode 2004-2009 melalui proses Pergantian Antar Waktu (PAW) pada tahun 2008 menggantikan Bong Wui Kong yang dipecat oleh Partai Perhimpunan Indonesia Baru (PIB). Pada periode 2009-2014, Tjhai Chui Mie terpilih menjadi Ketua DPRD Kota Singkawang setelah menempati urutan pertama perolehan suara karena mampu meraih suara tertinggi dari daerah pemilihannya yaitu Singkawang Barat sebesar 3.139 suara. Pada pemilu 2014, partai yang selama ini menaungi Tjhai Cui Mie yakni Partai PIB dinyatakan tidak lolos sebagai partai peserta pemilu 2014. Tjhai Cui Mie beralih ke Partai Demokrasi Indonesia Perjuangan (PDIP). Hasilnya adalah Tjhai Chui Mie tetap memperoleh suara tertinggi di Kota Singkawang melalui daerah pemilihan Singkawang Barat sebesar 3.103 suara yang mengantarkannya duduk kembali menjadi Anggota DPRD Singkawang periode 2014-2019.

Pengalaman politik merupakan penting bagi kandidat perempuan. Karena salah satu pertimbangan partai politik dalam mengusung calon adalah melihat latar belakang kandidat. Seperti yang diungkapkan oleh Baer \& Hartmann, kandidat perempuan sering mengalami pertanyaan yang lebih besar tentang kualifikasi mereka daripada kandidat laki-laki. Perempuan membutuhkan kesuksesan di tingkat yang lebih rendah untuk membangun kredibilitas pada jabatan yang lebih tinggi. Sementara laki-laki lebih mungkin dianggap berkualitas bahkan dengan pengalaman politik yang kurang. ${ }^{26}$

Kondisi ini tentunya berbeda dengan Tjhai Nyit Kim dimana dikenal masyarakat sebagai istri dari Walikota Singkawang 2012-2017 Awang Ishak. Tjhai Nyit Kim merupakan orang baru dalam politik dan dia juga pernah bertarung di Pemilu Legilatif tahun 2014 tetapi tidak terpilih. Sedangkan Tjhai Chui Mie bukan politikus karbitan dan dia dikenal sebagai anggota DPRD bahkan sudah 3 periode berpengalaman di bidang legislatif. ${ }^{27}$

${ }^{26}$ Stephen J. Stambough Stephen J. Stambough, "Political Experience and the Succes of Female Gubernatorial Candidates," Valerie R. O'Regan dan Stephen J. Stambough, "Political Experience and the Succes of Female Gubernatorial Candidates", Social Sciences Vol. 5 , 2016, h.2.

${ }^{27}$ Sumberanto Tjitra, "Sumberanto Tjitra, Wakil Ketua DPRD Singkawang, wawancara tanggal 18 Mei 2018.," 


\section{Mirnawati: CAPACITY BUILDING ORGANISASI; .....}

Memiliki modal sosial, modal ekonomi dan modal budaya inilah juga ditransformasi menjadi modal simbolik. Dengan simbol yang dimilikinya sebagai politikus perempuan dengan berpengalaman sebagai anggota legislatif, Tjhai Chui Mie memanfaatkannya dengan baik untuk meraih dukungan masyarakat. Tjhai Chui Mie sadar rekam jejaknya penting untuk membangun sebuah image politik. Seperti yang diungkapkan Harrop,image politik dapat mencerminkan tingkat kepercayaan dan kompetensi partai politik atau kandidat. Image politik adalah konstruksi atas representasi dan persepsi masyarakat (publik) akan suatu partai politik atau individu mengenai semua hal yang terkait dengan aktivitas politik. Image politik yang positif, cenderung akan memberi efek positif terhadap capaian suara. ${ }^{28}$

Cornelis sebagai ketua DPD PDIP Provinsi Kalbar dari tahun 2014 bahkan sudah menyatakan pada tahun 2017 Tjhai Chui Mie harus maju menjadi Calon Walikota Singkawang karena Tjhai Chui Mie merupakan kader terbaik yang dimiliki PDIP dan bisa menang. Dari pernyataan Cornelis itulah, imbasnya adalah dipromosikan dari mulut ke mulut sebagai calon Walikota Singkawang padahal masih dua tahun menjelang Pilkada. Sehingga Tjhai Chui Mie juga didukung oleh masyarakat di Singkawang bahkan pengusaha Tionghoa di Jakarta atau didaerah lainnya. ${ }^{29}$

Sebagai seorang kandidat calon walikota perempuan, Tjhai Chui Mie juga dalam berkampanye selalu memberikan motivasi dan contoh kepada perempuan bahwa perempuan bisa menjadi pemimpin. Ini dilihat ketika kampanye ketika Tjhai Chui Mie membawa program khusus pemberdayaan perempuan seperti pendidikan dan kesehatan. Dan belajar dari kekalahan Hasan Karman pada Pilwako tahun 2012 akibat terlalu menimbulkan simbol keetnisan Tionghoa tanpa mempertimbangkan perasaan etnis lain, contohnya dengan didirikannya Monumen Naga yang memicu terjadinya gesekan antaretnis dan agama di Singkawang sehingga Etnis Tionghoa pun tidak menyambut gembira pendirian Monumen Naga tersebut, Tjhai Chui Mie

${ }^{28}$ Firmanzah, Marketing Politik, (Jakarta: Yayasan Obor Indonesia, 2007), h. 229. (Jakarta: Yayasan Obor Indonesia, 2007).

${ }^{29}$ Tjhai Chui Mie, "Tjhai Chui Mie, walikota terpilih, wawancara tanggal 30 Mei 2018," 2018. 


\section{Mirnawati: CAPACITY BUILDING ORGANISASI; .....}

juga tidak lupa membangun image dirinya sebagai simbol calon pemimpin yang akan menjaga keharmonisan antar etnis Kota Singkawang mengingat Kota Singkawang yang multikultural dengan beragam etnis. Dalam kampanyenya ia menggunakan atraksi barongsai, kuda lumping, tanjidor dan gendang tahar untuk menarik dukungan masyarakat dan juga mengajak tokoh agama dalam berbagai kesempatan.

Kepemilikan modal merupakan sumber daya politik yang dapat digunakan untuk memenangkan Pilkada seperti yang terjadi pada Tjhai Chui Mie. Tjhai Chui Mie mampu mengakumulasi modal yang dimilikinya sehingga ia memenangkan Pilwako bukan melewati jalan pintas. Kandidat memiliki peluang besar terpilih manakala memiliki akumulasi lebih dari satu modal. Semakin besar kandidat yang mampu mengakumulasi modal tersebut, semakin berpeluang terpilih sebagai Kepala Daerah dan hal ini terbukti dengan keberhasilan Tjhai Chui Mie mejadi walikota terpilih. Kepemilikan modal dan bagaimana memanfaatkannya sebagai strategi menjadi penting dikarenakan Pilkada bukan menjadi wilayah persaingan antar partai tetapi kandidatlah yang menjadi aktor kunci dalam pilkada.

\section{KESIMPULAN}

Untuk memperoleh kemenangan dalam kontestasi Pemilihan Walikota dan Wakil Walikota Singkawang tahun 2017, Tjhai Chui Mie memiliki empat modal dan berhasil memanfaatkanya dengan baik yaitu modal sosial (rajin melakukan bakti sosial, jaringan sosial dan kepercayaan masyarakat), modal ekonomi (harta kekayaan dan dana kampanye), modal budaya (pendidikan formal dan warisan budaya dari keluarga etnis Tinghoa suku Hakka) dan modal simbolik (politikus perempuan etnis Tionghoa dengan jabatannya sebagai Anggota DPRD 3 periode). Modal merupakan sumber daya yang mutlak dimiliki kandidat untuk mendapatkan dukungan suara dari para pemilih. Oleh karena itu, ketika sudah memiliki modal yang akan digunakan dalam Pilkada, maka berikutnya adalah memilih strategi yang tepat dengan memanfaatkan modal yang sudah dimilki. Semakin besar akumulasi modal yang dimiliki oleh seorang kandidat maka semakin besar pula dukungan yang diperoleh. Untuk kandidat perempuan, maka membangun modal tersebut harus dijejaki jauh sebelum terjun menjadi 


\section{Mirnawati: CAPACITY BUILDING ORGANISASI; .....}

kandidat. Perempuan harus memulai rekam jejak itu dari awal.

\section{DAFTAR PUSTAKA}

Ali, M. Pilkada Serentak 2017 : Menyambut Perempuan Kepala Daerah.

Diakses 30 Desember 2017, dari http://satunama.org/3703/pilkadaserentak-2017-menyambut-perempuan-kepala-daerah/,2017

Baharuddin, T., \& Purwaningsih, T. Modalitas Calon Bupati Dalam Pilkada Tahun 2015; Studi Kasus Indah Putri Indriani Sebagai Bupati Terpilih di Kabupaten Luwu Utara Provinsi Sulawesi Selatan. Journal of Governance and Public Policy Vol. 4 No. 1 , 205-237, 2017

Bourdieu, P. The Forms of Capital. In J. Richardson, Handbook and Theory of Research for the Sociology of Education. New York: Greenwood, 1986

Davies, S. G., \& Idrus, N. I. Participating in Parliamentary Politics : Experiences of Indonesia Women 1995-2010. Journal of Indonesia Social Sciences and Humanities, 3, 2010

Fashri, F. Penyingkapan Kuasa Simbol: Apropriasi Reflektif Pemikiran Pierre Bourdieu. Yogyakarta: Juxtapose, 2007

Fashri, F. Pierre Bourdie, Menyingkap Kuasa Simbol. Yogyakarta: Jalasutra, 2014

Firmanzah. Marketing Politik. Jakarta: Yayasan Obor Indonesia, 2007 


\section{Mirnawati: CAPACITY BUILDING ORGANISASI; .....}

Fukuyama, F. Trust Kebijakan Sosial dan Penciptaan Kemakmuran. Yogyakarta: Qalam, 2002

Halim, A, Politik Lokal; Pola, Aktor \& Alur Dramatikalnya. Yogyakarta: LP2B, 2014

Harker, R., Mahar, C., \& Wilkes, C. (Habitus $x$ Modal $)+$ Ranah $=$ Praktik (Pengantar Paling Komprehensif kepada Pemikiran Pierre Bourdieu). Yogyakarta: Jalasutra, 2009

ICW.. Dana Kampanye dan Masa Kritis Pilkada 2017. Diakses pada https://antikorupsi.org/sites/default/files/files/Siaran\%20Pers/Rilis $\% 20$ dana\%20kampanye $\% 20$ dan $\% 20$ masa $\% 20$ kritis\%20pilkada.pd f . 19 September 2018, 2017

KPU. Penyelenggaraan Pilkada Serentak 2015 dan 2017. Jakarta: Komisi Pemilihan Umum, 2017

Miles, M. B., \& Huberman, A.. Analisis Data Kualitatif. Jakarta: Universitas Indonesia, 1992

Moleong, L. J. Metodologi Penelitian Kualitatif. Bandung: PT. Remaja Rosdakarya, 2005

Nurhasim, M., Mashad, D., Cahyono, H., Gayatri, 1. H., Dewi, K. H., Rozi, S., et al. Konflik antar Elit Politik Lokal dalam Pemilihan Kepala Daerah. Jakarta: Pusat Penelitian Politik (P2P) LIPI, 2003

O'Regan, V. R., \& Stambough, S. JPolitical Experience and the Succes of Female Gubernatorial Candidates. Social Sciences Vol. 5 , 1-12, . 2016

Saputra, N. Bagikan Seribu Kalender Berlambang Palu Arit, Ini Tanggapan Dewan Singkawang. Diakses 10 Agustus 2018, dari http://pontianak.tribunnews.com/2016/06/30/bagikan-15-ribukalender-yang-berlambang-palu-arit-ini-tanggapan-dewansingkawang, 2016

Sjaf, S. Ruang Pertarungan dan Strategi Aktor di Arena Ekonomi Politik Lokal. Jurnal Sosial Humaniora, 02, 145-156, 2011 


\section{Mirnawati: CAPACITY BUILDING ORGANISASI; .....}

Rafni, A. Akses dan Kontrol Politik Perempuan Etnis Cina dalam Pemilu Legislatif 2004 di Kota Padang. Demokrasi Vol. VI No. 2, 2007.

Windett, J. H. Understanding Female Candidates and Campaigns. Chapel Hill: University of North Carolina, 2011

Yayasan Satu Nama. Perempuan di Pilkada Serentak 2015, Perspektif Perempuan dan Lingkar Kekuasaan di Sekitaran Calon Perempuan Peserta Pilkada. Yogyakarta: Yayasan Satu Nama, 2016

Yew-Foong, H. Decentralization and Chinese Indonesian Politics: The Case of Singkawang, West Kalimantan. ISEAS Perspective (19), 2017. 